\title{
Extraction of matrine from Sophora flavescens Ait. and evaluation of its inhibitory effects on human nasopharyngeal carcinoma CNE-2 cells
}

\author{
Ming WANG ${ }^{1 *}$, Gang LIU ${ }^{1}$, Haiyan $\mathrm{LI}^{1}$
}

\begin{abstract}
The present study investigated the extraction and purification technology of matrine from Sophora flavescens Ait. and the inhibitory effects of matrine on human nasopharyngeal carcinoma (NPC) CNE-2 cells. The matrine was extracted from Sophora flavescens Ait. by decocting using ethanol-aqueous solution as the solvent, followed by purification using ion exchange resin adsorption. The extraction and purification conditions were investigated. The effects of matrine on growth, cell apoptosis and cycle of CNE- 2 cells and expressions of Bac- 2 and caspase- 3 protein in cells were detected. Results showed that, the optimal extraction and purification technologies of matrine from Sophora flavescens Ait. were obtained, under which the purity of matrine was $81.56 \%$. Matrine could obtain inhibit the growth of CNE-2 cells, promote the cell apoptosis, and arrest most cells in $\mathrm{G} 0 / \mathrm{G} 1$ phase. In addition, after treated matrine, the relative expression level of Bcl-2 protein in CNE-2 cells was decreased, and the expression level of Caspase- 3 protein was increased. In conclusion, matrine has inhibitory effects on human NPC CNE-2 cells. The mechanism may be related to its down-regulation of Bcl-2 protein and up-regulation of Caspase-3 protein expression.
\end{abstract}

Keywords: matrine; extraction; nasopharyngeal carcinoma; CNE-2.

Practical Application: Matrine extracted from Sophora flavescens Ait. has inhibitory effects on human nasopharyngeal carcinoma CNE-2 cells.

\section{Introduction}

Sophora flavescens Ait. is a traditional Chinese herbal medicine. It has anti-tumor, anti-inflammatory, and antiviral effects (Zheng et al., 2013; He et al., 2015). Matrine is the main active ingredient of Sophora flavescens. It is an important alkaloid, which has a high inhibitory rate on some tumor cells and transplanted tumors (Zhang et al., 2009; Liu et al., 2010). Nasopharyngeal carcinoma (NPC) is a common malignant tumor in Southeast Asia and southern China. About $92 \%$ of NPC cases occur in the less developed areas (Feng et al., 2011). Radiotherapy is the main treatment modality for NPC. The radical radiotherapy can achieve good curative effect for most early-stage NPC patients which can obtain long-term survival after treatment (Lee et al., 2002). However, the pathogenesis of NPC is often occult, and the patients do not have any discomfort. When diagnosed in the clinic, the majority of NPC patients are in advanced stage. Although the radiotherapy equipment and technology are constantly updated and improved, the recurrence rate and distant metastasis rate radiotherapy is high. Chemotherapy still occupies an important position for patients with advanced NPC. The current first-line chemotherapy drugs include platinum compounds and 5 -fluorouracil (Chan et al., 2002). However, some NPC patients, especially in advanced stage, have tolerance to these two drugs (You et al., 2015). Therefore, seeking effective and less-toxic drugs has important significance for the treatment of NPC, and it is one of the focuses in clinical research. At present, the research on the application of matrine to treatment of NPC is less reported. B-cell lymphoma-2 (Bcl-2) and Cysteine aspartic acid specific protease-3 (Caspase-3) are the proteins which play an important role in signal transduction of apoptosis (Zhan et al., 1999). This study investigated the extraction and purification technology of matrine from Sophora flavescens Ait. and the inhibitory effects of matrine on human NPC CNE- 2 cells and the mechanism related to $\mathrm{Bcl}-2$ and Caspase- 3 protein expressions. The objective was to provide an experimental basis to further application of matrine to treatment of NPC.

\section{Materials and methods}

\subsection{Materials}

Sophora flavescens Ait. was provided by Shaanxi Dahe Pharmaceutical Co., Ltd., (Xian, China). Human NPC CNE-2 cells were purchased from Typical Culture Preservation Committee Cell Bank of Chinese Academy of Sciences (Beijing, China). ter). Other reagents were purchased from Sigma-Aldrich Corp. (MO, USA).

\subsection{Extraction and purification of matrine}

Matrine was extracted from Sophora flavescens Ait. by decocting using ethanol-aqueous solution as the solvent. The effects of extraction conditions including ethanol concentration, solvent amount, extraction time and extraction times on the content of decocting product were investigated by single factor experiments. Based on this, the extraction parameters were 
further optimized through Box-Behnken central composite design and response surface analysis. The content of decocting was used as the analysis and evaluation index. The crude matrine product obtained in above extraction was dissolved using $0.5 \%$ hydrochloric acid. After filtration, the alkalization was performed using pH 12 ammonia water. Finally, the matrine was further purified using ion exchange resin adsorption. The static and dynamic adsorption experiments were made, and the amount of macroporous resin, sample loading solution content and eluting conditions were determined.

\subsection{Culture of CNE-2 cells}

CNE- 2 cells were cultured with RPMI-1640 medium containing $10 \%$ FBS, $0.1 \mathrm{mg} / \mathrm{ml}$ streptomycin and $100 \mathrm{IU} / \mathrm{ml}$ penicillin ( $37{ }^{\circ} \mathrm{C}, 5 \% \mathrm{CO}_{2}$, saturated humidity). The growth of cells was observed under the microscope. When the cells were confluent to $80 \%-90 \%$, the culture medium was discarded. After washing with PBS for two times, $0.25 \%$ trypsin (containing $0.02 \%$ EDTA) was added for digestion for $5 \mathrm{~min}$. When cytoplasmic retraction and cell gap increase appeared, the digestion was immediately terminated. The single cell suspension was prepared, followed by passage for 2-3 days. The cells in logarithmic growth phase were used for the further experiments.

\subsection{Determination of CNE-2 cell activity}

Activity of CNE- 2 cells was determined by MTT method. The cells with concentration of $2 \times 10^{5} \mathrm{cell} / \mathrm{mL}$ were incubated in 96-well culture plate, $100 \mu \mathrm{L}$ for each well. After $48 \mathrm{~h}$ the original medium was removed. The cells were divided into control and 50, 100, 200 and $400 \mathrm{mg} / \mathrm{L}$ matrine groups, 5 wells in each group. In matrine groups, the matrine was added to the well, with final matrine concentration of 50, 100, 200 and $400 \mathrm{mg} / \mathrm{L}$, respectively. In control group, DMSO solution was added. After culture for 12, 24 and $48 \mathrm{~h}$, the culture medium was discarded and $10 \mu \mathrm{L}$ MTT was added, followed by culture for $6 \mathrm{~h}$. Moderate volume of DMSO was added to the well, followed by oscillation for $10 \mathrm{~min}$. The optical density (OD) of each well was detected at the wavelength of $650 \mathrm{~nm}$. The cell growth inhibition rate was calculated as follows: cell growth inhibition rate $=\left(\mathrm{OD}_{\text {control group }}-\mathrm{OD}_{\text {matrine group }}\right) / \mathrm{OD}_{\text {control group }} \times 100 \%$.

\subsection{Detection of CNE-2 cell apoptosis and cycle}

Flow cytometry was performed to detect the cycle and apoptosis of CNE- 2 cells. The CNE-2 cells were treatment with matrine for $48 \mathrm{~h}$. After discarding the culture medium, the cell solution was centrifuged at $200 \mathrm{Xg}$ for $10 \mathrm{~min}$, followed by washing with PBS for 2 times. Propidium iodide and RNA enzyme without DNA enzyme contamination were added, with final of concentration of $20 \mu \mathrm{g} / \mathrm{mL}$. After dyeing for $1 \mathrm{~h}$, the cell apoptosis and cell cycle were measured by flow cytometry.

\subsection{Detection of Bac-2 and caspase-3 protein expression}

CNE- 2 cells were treatment with matrine for $48 \mathrm{~h}$. The culture medium was discarded. The cells were collected, followed by lysing. After centrifugation at $200 \mathrm{Xg}$ for $10 \mathrm{~min}$, the supernatant was obtained and the protein concentration was measured using the bicinchoninic acid method. The expressions of Bac-2 and caspase- 3 protein were determined using Western blotting assay. The procedure was in accordance with the instructions of kits. $\beta$-actin was used as the internal reference. The relative expression level of target protein was presented by the ratio of integral optical density of target protein to $\beta$-actin (Fan et al., 2005).

\subsection{Statistical analysis}

Each experiment was performed for 3 times. The data were presented as mean $\pm \mathrm{SD}$. All statistical analysis was carried out using SPSS 20.0 software (SPSS Inc., Chicago, IL, USA). The difference between among different groups was analyzed using single factor analysis of variance with LSD- $t$ test. $P<0.05$ was considered as statistically significant.

\section{Results}

\subsection{Extraction and purification results}

Results of single factor experiments and response surface analysis based on central composite design showed that, the optimum extraction conditions of matrine from Sophora flavescens Ait. were as follows: ethanol concentration, $60 \%$; ratio of solvent to material, $4: 1 \mathrm{~mL} / \mathrm{g}$; extraction time, $2 \mathrm{~h}$; extraction frequency, 3 times. Under these conditions, the content of baicalin extract was $8.53 \%$. The separation and purification conditions of ion exchange resin adsorption were as follows: the ratio of sample loading solution volume to mass of the resin was $5: 1 \mathrm{~mL} / \mathrm{g}$; the sample loading flow rate was $6 \mathrm{ml} / \mathrm{min}$; the concentration of sample loading solution was $8 \mathrm{mg} / \mathrm{ml}$; the water was firstly used to elute the impurity, followed by using concentration $80 \%$ ethanol water solution to elute the matrine. Finally, the purity of matrine was $81.56 \%$.

\subsection{Effect of matrine on the growth of CNE-2 cells}

Inhibition rate of matrine on CNE-2 cells increased with the increase of matrine concentration or extending of treatment time. When the treatment time was $48 \mathrm{~h}$, the inhibition rate of $400 \mathrm{mg} / \mathrm{L}$ matrine group was $36.3 \pm 4.7 \%$, which was the highest among four groups. In other three groups, the matrine showed a relatively weak inhibitory effect on the growth of CNE-2 cells (Table 1).

\subsection{Effect of matrine on apoptosis of CNE-2 cells}

As shown in Figure 1, after treated with matrine for $48 \mathrm{~h}$, the apoptosis rate of CNE- 2 cells increased with the increase of matrine concentration. The apoptosis rates in 50, 100, 200 and $400 \mathrm{mg} / \mathrm{L}$

Table 1. Effect of matrine on growth of CNE-2 cells.

\begin{tabular}{cccc}
\hline \multirow{2}{*}{ Group } & \multicolumn{3}{c}{ Inhibition rate (\%) } \\
\cline { 2 - 4 } & $12 \mathrm{~h}$ & $24 \mathrm{~h}$ & $48 \mathrm{~h}$ \\
\hline $50 \mathrm{mg} / \mathrm{L}$ matrine & $0.6 \pm 0.1$ & $0.8 \pm 0.1$ & $0.9 \pm 0.2$ \\
$100 \mathrm{mg} / \mathrm{L}$ matrine & $5.6 \pm 0.7^{\mathrm{a}}$ & $8.1 \pm 1.3^{\mathrm{a}}$ & $13.2 \pm 2.1^{\mathrm{a}}$ \\
$200 \mathrm{mg} / \mathrm{L}$ matrine & $9.2 \pm 1.7^{\mathrm{ab}}$ & $14.2 \pm 2.8^{\mathrm{ab}}$ & $21.2 \pm 3.4^{\mathrm{ab}}$ \\
$400 \mathrm{mg} / \mathrm{L}$ matrine & $13.3 \pm 2.1^{\mathrm{abc}}$ & $18.1 \pm 3.1^{\mathrm{ab}}$ & $36.3 \pm 4.7^{\mathrm{abc}}$ \\
\hline${ }^{\mathrm{a}} \mathrm{P}<0.05$ compared with $50 \mathrm{mg} / \mathrm{L}$ matrine group; ${ }^{\mathrm{b}} \mathrm{P}<0.05$ compared with $100 \mathrm{mg} / \mathrm{L}$ \\
matrine group; ${ }^{\mathrm{P} P}<0.05$ compared with $200 \mathrm{mg} / \mathrm{L}$ matrine group.
\end{tabular}


matrine groups were significantly higher than that in $0 \mathrm{mg} / \mathrm{L}$ matrine group, respectively $(\mathrm{P}<0.05)$. In addition, the apoptosis rate in 200 and $400 \mathrm{mg} / \mathrm{L}$ matrine group was significantly higher than that in 50 and $100 \mathrm{mg} / \mathrm{L}$ matrine group, respectively $(\mathrm{P}<0.05)$.

\subsection{Effect of matrine on cycle of CNE-2 cells}

After treated with matrine for $48 \mathrm{~h}$, the percentage of CNE-2 cells in G0/G1 phase in 50, 100, 200 and $400 \mathrm{mg} / \mathrm{L}$ matrine group were significantly higher than that in $0 \mathrm{mg} / \mathrm{L}$ matrine group, respectively $(\mathrm{P}<0.05)$, and the percentage of $\mathrm{CNE}-2$ cells in $\mathrm{S}$ phase in four matrine groups were significantly lower than that in $0 \mathrm{mg} / \mathrm{L}$ matrine group, respectively $(\mathrm{P}<0.05)$. The percentage of CNE-2 cells in M phase in 100, 200 and $400 \mathrm{mg} / \mathrm{L}$ matrine group was significantly lower than that in 0 and $50 \mathrm{mg} / \mathrm{L}$ matrine group, respectively $(\mathrm{P}<0.05)$ (Table 2$)$.

\subsection{Effect of matrine on expression of Bac-2 and Caspase-3 protein in $\mathrm{CNE}-2$ cells}

With the increase of matrine concentration, the relative expression level of $\mathrm{Bcl}-2$ protein in CNE-2 cells was decreased, and the expression level of Caspase-3 protein was increased.

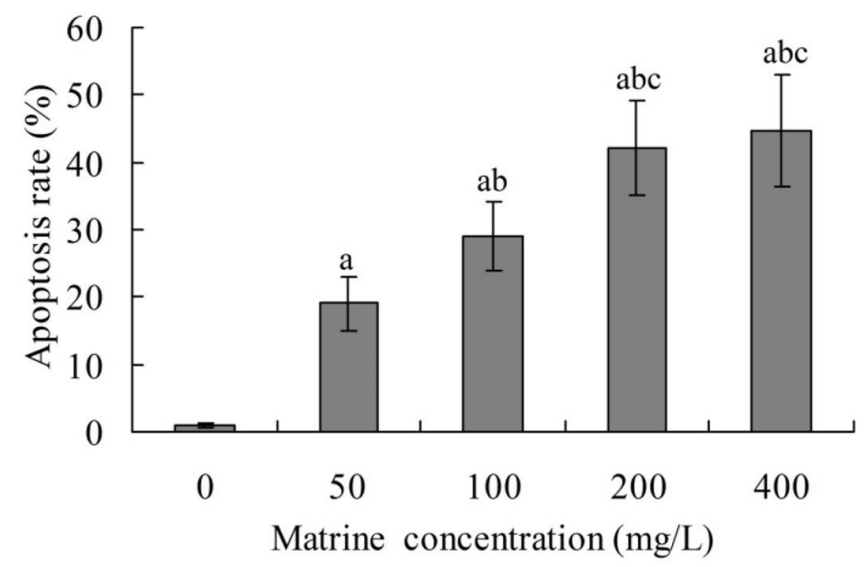

Figure 1. Effect of matrine on apoptosis of CNE-2 cells. ${ }^{\text {aP }}<0.05$ compared with $0 \mathrm{mg} / \mathrm{L}$ matrine group; ${ }^{\mathrm{b}} \mathrm{P}<0.05$ compared with $50 \mathrm{mg} / \mathrm{L}$ matrine group; ${ }^{\mathrm{P}}<0.05$ compared with $100 \mathrm{mg} / \mathrm{L}$ matrine group.
In $400 \mathrm{mg} / \mathrm{L}$ matrine group, the relative expression level of $\mathrm{Bcl}-2$ protein was the lowest, which was $1.1 \pm 0.3$, and the relative expression level of Caspase- 3 protein was the highest, which was $3.1 \pm 0.4$ (Figure 2).

\section{Discussion}

Matrine is a kind of alkaloid extracted from Sophora flavescens Ait. The molecular formula was $\mathrm{C}_{15} \mathrm{H}_{24} \mathrm{~N}_{2} \mathrm{O}$, with molecular weight of 248.36. A number of pharmacological studies and clinical practice have shown that, matrine can be used in the treatment of hepatitis, arrhythmias and ischemia (Zhang et al., 2011; Hu et al., 1996; Zhu et al., 2003). At the same time, matrine has the definite functions in calming, relieving pain, regulating body temperature, enhancing myocardial function, treating hypertension, and even the antiviral therapy ( $\mathrm{Li}$ et al., 2010; Liu et al., 2015). In addition, matrine plays an important role in anti-tumor treatment, immune regulation, and other aspects (Liu et al., 2014; Zhang et al., 2015). The anti-tumor role of matrine has been paid more and more attention by researchers. The anti-tumor mechanism of matrine can be summarized as follows: i) matrine can induce the differentiation of tumor cells and inhibit their proliferation in a certain extent; ii) matrine can promote the further apoptosis of tumor cells; iii) matrine can inhibit the adhesion of tumor cell and prevent the tumor cell invasion and metastasis; iv) matrine can reverse the tumor resistance, reduce the side effects of chemotherapy drugs, improve the life quality of patients, and prolong their survival time.

Table 2. Effect of matrine on cycle of CNE-2 cells (\%).

\begin{tabular}{cccc}
\hline $\begin{array}{c}\text { Matrine } \\
\text { concentration } \\
(\mathrm{mg} / \mathrm{L})\end{array}$ & G0/G1 phase & S phase & M phase \\
\hline 0 & $37 \pm 1$ & $44 \pm 1$ & $19 \pm 2$ \\
50 & $57 \pm 1^{\mathrm{a}}$ & $25 \pm 1^{\mathrm{a}}$ & $18 \pm 1$ \\
100 & $63 \pm 1^{\mathrm{ab}}$ & $22 \pm 1^{\mathrm{ab}}$ & $15 \pm 1^{\mathrm{ab}}$ \\
200 & $75 \pm 2^{\mathrm{abc}}$ & $17 \pm 1^{\mathrm{abc}}$ & $8 \pm 1^{\mathrm{abc}}$ \\
400 & $77 \pm 3^{\mathrm{abc}}$ & $16 \pm 1^{\mathrm{abc}}$ & $7 \pm 1^{\mathrm{ac}}$ \\
\hline
\end{tabular}

${ }^{\text {a }} \mathrm{P}<0.05$ compared with $0 \mathrm{mg} / \mathrm{L}$ matrine group; ${ }^{\mathrm{b}} \mathrm{P}<0.05$ compared with $50 \mathrm{mg} / \mathrm{L}$ matrine group; ${ }^{\mathrm{C}} \mathrm{P}<0.05$ compared with $100 \mathrm{mg} / \mathrm{L}$ matrine group.
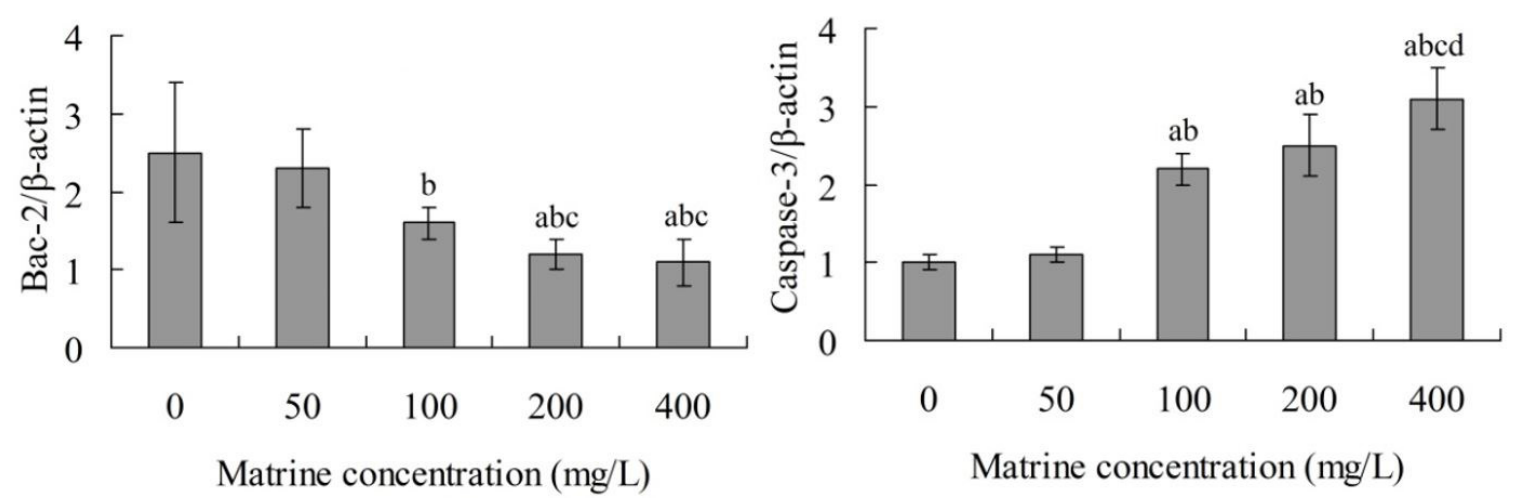

Figure 2. Effect of matrine on expression of Bac- 2 and Caspase- 3 protein in CNE- 2 cells. ${ }^{a} \mathrm{P}<0.05$ compared with 0 mg $/ \mathrm{L}$ matrine group; ${ }^{b} \mathrm{P}<0.05$ compared with $50 \mathrm{mg} / \mathrm{L}$ matrine group; ${ }^{\mathrm{C}} \mathrm{P}<0.05$ compared with $100 \mathrm{mg} / \mathrm{L}$ matrine group; ${ }^{\mathrm{d}} \mathrm{P}<0.05$ compared with $200 \mathrm{mg} / \mathrm{L}$ matrine group. 
The effects of matrine on induced tumor cell differentiation, proliferation and apoptosis are the focus of recent researches.

This study investigated the extraction and purification technology of matrine from Sophora flavescens Ait.. After the single factor experiments and the optimization experiment through Box-Behnken central composite design and response surface analysis, the optimal extraction conditions were obtained. In addition, through the acidification and alkalization treatment, the impurities in the crude matrine product were removed. After ion exchange resin adsorption, the final matrine product was obtained, which had a purity of $81.56 \%$. This indicate that, the extraction and purification technology of matrine from Sophora flavescens Ait. developed in this study is relatively satisfactory. Next, the inhibitory effects of matrine on human NPC CNE- 2 cells were evaluated. Results showed that, matrine could obtain inhibit the growth of CNE-2 cells, promote the cell apoptosis, and arrest most CNE-2 cells in G0/G1 phase. This indicates that, matrine has inhibitory effects of CNE- 2 cells.

The occurrence and development of tumor are related to many factors, but the decrease of apoptosis is one of the key factors (Fulda, 2009). Clinical practice shows that, the use of Chinese medicine alone or combination of traditional Chinese and Western medicine can obtain definite curative effect in treatment of certain tumors (Liu et al., 2013). The induction of tumor cell apoptosis is one of the main ways of treatment of malignant tumors (Fulda, 2009). Apoptosis is a basic cell biological phenomenon. From the aspect of genetic programming regulation, the apoptosis can be called the programmed cell death (Elmore, 2007). The signal transduction pathways of apoptosis are diverse, and many pathways promote or restrict each other, thus forming a perplexing regulatory network. Among them, Bcl-2 and Caspase-3 proteins play an important role in signal transduction of apoptosis (Zhan et al., 1999). Results of this study showed that, after treated matrine, the relative expression level of $\mathrm{Bcl}-2$ protein in CNE-2 cells was decreased, and the expression level of Caspase-3 protein was increased. This indicates that, emodin can down-regulate the expression of $\mathrm{Bcl}-2$ protein and up-regulate the expression of Caspase- 3 protein in CNE- 2 cells, which may be related to its inhibitory effect on CNE- 2 cells.

\section{Conclusion}

This study has obtained the relatively optimal extraction and purification technology of matrine from Sophora flavescens Ait., under which the purity of matrine is $81.56 \%$. In addition, the in vitro experiments indicate that, matrine has inhibitory effects on human NPC CNE-2 cells. The mechanism may be related to its down-regulation of $\mathrm{Bcl}-2$ protein and up-regulation of Caspase- 3 protein expression. This study has provides an experimental basis the clinical application of matrine to treatment of NPC.

\section{References}

Chan, A. T., Teo, P. M., Ngan, R. K., Leung, T. W., Lau, W. H., Zee, B., Leung, S. F., Cheung, F. Y., Yeo, W., Yiu, H. H., Yu, K. H., Chiu, K. W., Chan, D. T., Mok, T., Yuen, K. T., Mo, F., Lai, M., Kwan, W. H., Choi, P., \& Johnson, P. J. (2002). Concurrent chemotherapy-radiotherapy compared with radiotherapy alone in locoregionally advanced nasopharyngeal carcinoma: progression-free survival analysis of a phase III randomized trial. Journal of Clinical Oncology, 20(8), 20382044. http://dx.doi.org/10.1200/JCO.2002.08.149. PMid:11956263.

Elmore, S. (2007). Apoptosis: a review of programmed cell death. Toxicologic Pathology, 35(4), 495-516. http://dx.doi.org/10.1080/01926230701320337. PMid:17562483.

Fan, X. J., Guo, K., Xiao, B., Zi, X. H., \& Song, Z. (2005). Effects of sodium aescinate on bcl-2 and caspase-3 expression and apoptosis after focal cerebral ischemia reperfusion injury in rats. Journal of Central South University, 30(3), 261-265, 275. PMid:16045009.

Feng, X., Zhang, J., Chen, W. N., \& Ching, C. B. (2011). Proteome profiling of Epstein-Barr virus infected nasopharyngeal carcinoma cell line: identification of potential biomarkers by comparative iTRAQcoupled 2D LC/MS-MS analysis. Journal of Proteomics, 74(4), 567576. http://dx.doi.org/10.1016/j.jprot.2011.01.017. PMid:21296196.

Fulda, S. (2009). Tumor resistance to apoptosis. International Journal of Cancer, 124(3), 511-515. http://dx.doi.org/10.1002/ijc.24064. PMid:19003982.

He, X., Fang, J., Huang, L., Wang, J., \& Huang, X. (2015). Sophora flavescens Ait.: Traditional usage, phytochemistry and pharmacology of an important traditional Chinese medicine. Journal of Ethnopharmacology, 172, 10-29. http://dx.doi.org/10.1016/j.jep.2015.06.010. PMid:26087234.

Hu, Z. L., Zhang, J. P., Yu, X. B., Lin, W., Qian, D. H., \& Wan, M. B. (1996). Effect of matrine on lipopolysaccharides/D-galactosamine-induced hepatitis and tumor necrosis factor release from macrophages in vitro. Acta Pharmacologica Sinica, 17(4), 351-353. PMid:9812722.

Lee, N., Xia, P., Quivey, J. M., Sultanem, K., Poon, I., Akazawa, C., Akazawa, P., Weinberg, V., \& Fu, K. K. (2002). Intensity-modulated radiotherapy in the treatment of nasopharyngeal carcinoma: an update of the UCSF experience. International Journal of Radiation Oncology, Biology, Physics, 53(1), 12-22. http://dx.doi.org/10.1016/ S0360-3016(02)02724-4. PMid:12007936.

Li, X., Zhou, R., Zheng, P., Yan, L., Wu, Y., Xiao, X., \& Dai, G. (2010). Cardioprotective effect of matrine on isoproterenol-induced cardiotoxicity in rats. The Journal of Pharmacy and Pharmacology, 62(4), 514-520. http://dx.doi.org/10.1211/jpp.62.04.0015. PMid:20604842.

Liu, T., Song, Y., Chen, H., Pan, S., \& Sun, X. (2010). Matrine inhibits proliferation and induces apoptosis of pancreatic cancer cells in vitro and in vivo. Biological \& Pharmaceutical Bulletin, 33(10), 1740-1745. http://dx.doi.org/10.1248/bpb.33.1740. PMid:20930385.

Liu, Y., Xu, Y., Ji, W., Li, X., Sun, B., Gao, Q., \& Su, C. (2014). Anti-tumor activities of matrine and oxymatrine: literature review. Tumour Biology, 35(6), 5111-5119. http://dx.doi.org/10.1007/s13277-0141680-z. PMid:24526416.

Liu, Z. W., Wang, J. K., Qiu, C., Guan, G. C., Liu, X. H., Li, S. J., \& Deng, Z. R. (2015). Matrine pretreatment improves cardiac function in rats with diabetic cardiomyopathy via suppressing ROS/TLR-4 signaling pathway. Acta Pharmacologica Sinica, 36(3), 323-333. http://dx.doi. org/10.1038/aps.2014.127. PMid:25619390.

Liu, Z., Chen, S., Cai, J., Zhang, E., Lan, L., Zheng, J., Liao, L., Yang, X., Zhou, C., \& Du, J. (2013). Traditional Chinese medicine syndromerelated herbal prescriptions in treatment of malignant tumors. Journal of Traditional Chinese Medicine, 33(1), 19-26. http://dx.doi. org/10.1016/S0254-6272(13)60095-3. PMid:23596807.

You, Y., Yang, W., Qin, X., Wang, F., Li, H., Lin, C., Li, W., Gu, C., Zhang, Y., \& Ran, Y. (2015). ECRG4 acts as a tumor suppressor and as a determinant of chemotherapy resistance in human nasopharyngeal carcinoma. Cellular Oncology (Dordrecht), 38(3), 205-214. http:// dx.doi.org/10.1007/s13402-015-0223-y. PMid:25707757.

Zhang, L., Zhang, H., Zhu, Z., Jiang, L., Lu, X., Zhou, M., Sun, X., He, L., Bai, Y., \& Ma, L. (2015). Matrine regulates immune functions to 
inhibit the proliferation of leukemic cells. International Journal of Clinical and Experimental Medicine, 8(4), 5591-5600. PMid:26131142.

Zhan, Y., van de Water, B., Wang, Y., \& Stevens, J. L. (1999). The roles of caspase-3 and bcl-2 in chemically-induced apoptosis but not necrosis of renal epithelial cells. Oncogene, 18(47), 6505-6512. http:// dx.doi.org/10.1038/sj.onc.1203060. PMid:10597253.

Zhang, Y., Zhang, H., Yu, P., Liu, Q., Liu, K., Duan, H., Luan, G., Yagasaki, K., \& Zhang, G. (2009). Effects of matrine against the growth of human lung cancer and hepatoma cells as well as lung cancer cell migration. Cytotechnology, 59(3), 191-200. http://dx.doi. org/10.1007/s10616-009-9211-2. PMid:19649719.
Zhang, Y., Zou, Y. N., \& Hao, D. X. (2011). Electrophysiological effects of matrine on guinea pigs with hypocalcemia-induced arrhythmia. Chinese Journal of Basic Medicine in Traditional Chinese Medicine, 17(6), 633-632.

Zheng, K., Li, C., Shan, X., Liu, H., Fan, W., \& Wang, Z. (2013). A study on isolation of chemical constituents from Sophora flavescens Ait. and their anti-glioma effects. African Journal of Traditional, Complementary, and Alternative Medicines, 11(1), 156-160. PMid:24653570.

Zhu, X. H., Qiu, Y. D., Shi, M. K., Wu, B., Zheng, X. G., \& Ding, Y. T. (2003). Effect of matrine on cold ischemia and reperfusion injury of sinusoidal endothelial cells in rat orthotopic liver transplantation. Acta Pharmacologica Sinica, 24(2), 169-174. PMid:12546726. 